\title{
Plant Histochemistry: A Versatile and Indispensible Tool in Localization of Gene Expression, Enzymes, Cytokines, Secondary Metabolites and Detection of Plants Infection and Pollution
}

\section{Farid A Badria* and Walaa S Aboelmaaty}

Department of Pharmacognosy, Mansoura University, Faculty of Pharmacy, Mansoura, Egypt

*Corresponding Author: Farid A Badria, Department of Pharmacognosy, Mansoura University, Faculty of Pharmacy, Mansoura, Egypt

Received: June 12, 2019; Published: June 20, 2019

DOI: $10.31080 /$ ASPS.2019.03.0318

\begin{abstract}
Plants are sources of active metabolites used in medicine and primary sources for isolation of natural products. The medicinal properties of plants are due to the presence of secondary metabolites, including flavonoids, alkaloids, tannins, and saponins, which are of great importance because they possess significant biological activities and the particular active constituents of many crude drugs are still unknown. Histochemical studies are used to confirm identification of cellular and tissue chemical components (secondary metabolites). Histochemical methods are employed in the identification, density of accumulation and distribution of chemical compounds within biological cells and tissues in different organs under microscopes using the color-stain reaction technique and photographic recording. These include the preparation of fixed variably stained specimens and then the examination under the microscopic devices. It is successfully applied in detection and localization of cellular components of active cell constituents such as proteins, carbohydrates, lipids, nucleic acids, and a range of ionic elements occurring in the cell solutions, in addition to identifying the characterization of secretory structures and the chemical nature of the secreted compounds. The methods played a role in describing and tracing the ultrastructure development during different plant growth stages so as the genetic bases of plant physiological and biochemical processes could be further elucidated.
\end{abstract}

Keywords: Histochemical Localization; Histochemistry; Color-Stain; Secondary Metabolites

\section{Introduction}

Histochemistry is the branch of histology dealing with the identification of chemical components of cells and tissues. Starch deposition occurs widely in the plant body, but the particularly common places of its accumulation are seeds, the parenchyma of the secondary vascular tissues in the stem and root, tubers, rhizomes and corn [1]. Starch and proteins are the principal ergastic substances of the protoplast [2]. Tannin is the heterogeneous group of phenol derivatives, usually related to glucosides. Tannins are particularly abundant in the leaves (xylem) of many plants [3]. Saponins are the rare occurrence. Fats are widely distributed in the plant body and they probably occur in small amount in every plant cell [4]. Fats are common reserve material inseeds, spores and embryos in meristematic cells. Glucosides are the degradation product of the carbohydrates. Alkaloids are the degradation product of protein. Many plants contain medicinally important secondary product [5].

Histochemistry is devoted to study the identification and distribution of chemical compoundswithin and between biological cells, using stains, indicators and light and electron microscopy [6].
Histochemical analysis is essential for the study of plant secretory structures whose classification is based, atleast partially, on the composition of their secretion. As each gland may produce one or more types of substances, a correct analysis of its secretion should be done using various histochemical tests to detect metabolites of different chemical classes [7].

Histochemistry is a methodological approach that allows the chemical analysis of cells and tissues in relation to their structural organization [8], but to achieve this objective for plant secretory structures, a wide histochemical analysis is necessary because the same gland and even the same glandular cell can produce several different metabolites simultaneously [9-11].

\section{Materials and Methods}

As the histochemical analysis of plant secretory structures uses reagents and dyes that are not specific, certain precautions should be taken to correctly interpret the results: (1) The natural color of the secretion should be observed in vivo before applying the test(avoiding the use of reagents with the same color as the 
secretion), (2) Attention should be paid to the color obtained in the staining since different colors can be generated in each test but the positive staining is specific and (3) The control procedure should be carefully set up, which usually consists of removing the substance to be detected prior to the test application. The color of the test and that of the control are compared visually to interpret the result [7].

All regents described below may be applied to fresh or fixed material. If it is necessary to use fixed material, the best fixative for hydrophilic substances is formalin-aceto-alcohol (FAA). For fixation, the material should be immersed in the FAA under vacuum for $24 \mathrm{~h}$, then washed in $50 \%$ ethanol overnight and stored in $70 \%$ ethanol [12].

Some stains that are commonly used in histochemical localization and their methodology are illustrated in Table 1 for hydrophilic, lipophilic substances, phenolic compounds and alkaloids.

\begin{tabular}{|l|l|}
\hline \multicolumn{2}{|c|}{ Detection of Hydrophilic substances } \\
\hline \multicolumn{1}{|c|}{\begin{tabular}{l}
\multicolumn{1}{c|}{ Mucilage } \\
red \\
staining
\end{tabular}} & $\begin{array}{l}\text { This method stains acidic mucilages, pectins [12, } \\
\text { 13] and nucleic acids magenta or red (Figure 1a). } \\
\text { 1. Apply 0.1\% ruthenium red to sections for 5 } \\
\text { min. } \\
\text { 2. Wash sections twice in distilled water to re- } \\
\text { move surplus stain. } \\
\text { 3. Mount the sections between slide and coverslip } \\
\text { with glyceringelatin. }\end{array}$ \\
\hline $\begin{array}{l}\text { Alcian Blue } \\
\text { Staining }\end{array}$ & $\begin{array}{l}\text { This test has a similar result as ruthenium red, } \\
\text { staining acidic mucilages, pectins [14] and nucle- } \\
\text { ic acids light blue (Figure 1b). } \\
\text { 1. Stain sections with 1\% Alcian Blue for 30 min. } \\
\text { 2. Rinse sections twice with distilled water to re- } \\
\text { move surplus stain. } \\
\text { 3. Mount the slide with glyceringelatin. }\end{array}$ \\
\hline $\begin{array}{l}\text { Tannic Acid } \\
\text { and Ferric } \\
\text { Chloride }\end{array}$ & $\begin{array}{l}\text { This method is based on the reaction of tannic } \\
\text { acid with mucilages [15] and pectins, substances } \\
\text { which are further revealed by the addition of fer- } \\
\text { ric chloride, producing a grey to black color (Fig- } \\
\text { ure 1c). } \\
\text { 1. Apply 5\% tannic acid for 20 min. } \\
\text { 2. Rinse briefly with distilled water. } \\
\text { 3. Submerge sections in 3\% ferric chloride for } \\
\text { 5min. } \\
\text { 4. Wash twice in distilled water to remove sur- } \\
\text { plus ferric chloride. } \\
\text { 5. Mount the sections using glyceringelatin. } \\
\text { 6. Control: Compare the staining obtained in the } \\
\text { test with that of sections treated only with tannic } \\
\text { acid or with ferric chloride. }\end{array}$ \\
\hline Starch
\end{tabular}

\begin{tabular}{|c|c|}
\hline $\begin{array}{l}\text { Lugol's } \\
\text { Reagent }\end{array}$ & $\begin{array}{l}\text { This reaction highlights the starch grains in dark } \\
\text { blue to black (Figure } 1 \mathrm{~d} \text { ) [12]. Almost all other } \\
\text { structures stain yellow, but this color has no spe- } \\
\text { cific significance. } \\
\text { 1. Submerge the sections in the Lugol's reagent } \\
\text { for } 10 \text { min. } \\
\text { 2. Rinse briefly with distilled water. } \\
\text { 3. Mount the slides using distilled water or Lu- } \\
\text { gol's reagent itself. }\end{array}$ \\
\hline $\begin{array}{l}\text { Triple } \\
\text { Staining for } \\
\text { Starch } \\
\text { Detection }\end{array}$ & $\begin{array}{l}\text { This triple staining was developed to analyze } \\
\text { structural tissue components and the starch } \\
\text { grains concomitantly [16]. The application of } \\
\text { safranin, astra blue and iodine-potassium iodide } \\
\text { solution stains starch grains black, acidic sub- } \\
\text { stances (e.g., nucleic acids and lignin) brown, and } \\
\text { non-lignified cell walls green (Figure 1e). } \\
\text { 1. Stain the sections with } 1 \% \text { safranin for } 1 \text { min. } \\
\text { 2. Rinse } 3 \text { times for few seconds in } 50 \% \text { ethanol } \\
\text { to remove surplus stain. } \\
\text { 3. Stain with } 1 \% \text { astra blue for } 1 \text { min. } \\
\text { 4. Wash three times for few seconds in distilled } \\
\text { water to remove surplus stain. } \\
\text { 5. Apply the iodine-potassium iodide solution for } \\
\text { 10 min. } \\
\text { 6. Dip sections rapidly in distilled water. } \\
\text { 7. Mount the slide with the smallest amount of } \\
\text { water. }\end{array}$ \\
\hline \multicolumn{2}{|c|}{ Carbohydrates } \\
\hline $\begin{array}{l}\text { PAS } \\
\text { Reaction } \\
\text { (Periodic } \\
\text { Acid: } \\
\text { Schiff's } \\
\text { reagent) }\end{array}$ & $\begin{array}{l}\text { This method is based on the reaction of peri- } \\
\text { odic acid with carbohydrates, forming carbonyl } \\
\text { groups revealed by Schiff's reagent [17]. Carbo- } \\
\text { hydrates stain magenta (Figure 1f). } \\
\text { 1. Apply } 1 \% \text { sodium tetraborate (freshly pre- } \\
\text { pared) for } 30 \text { min. } \\
\text { 2. Transfer sections to } 1 \% \text { periodic acid for } 10 \\
\text { min. } \\
\text { 3. Rinse briefly in distilled water. } \\
\text { 4. Apply Schiff's reagent for } 15 \text { min in dark. } \\
\text { 5. Wash the sections with sodium metabisulfite } \\
\text { for } 10 \text { min. } \\
\text { 6. Rinse in tap water for } 10 \text { min. } \\
\text { 7. Mount the slides using glyceringelatin. } \\
\text { 8. Control: Repeat the test excluding step } 2 \text { (pe- } \\
\text { riodic acid). }\end{array}$ \\
\hline $\begin{array}{l}\text { Aniline Blue } \\
\text { Staining }\end{array}$ & $\begin{array}{l}\text { This staining marks callose, which may be detect- } \\
\text { ed by a green fluorescence under UV light (Figure } \\
1 \mathrm{~g} \text { [ [18]. } \\
\text { 1. Apply } 0.05 \% \text { aniline blue for } 10 \text { min. } \\
\text { 2. Rinse briefly in distilled water. } \\
\text { 3. Mount the slide in the same buffer used for } \\
\text { staining. }\end{array}$ \\
\hline
\end{tabular}




\begin{tabular}{|c|c|c|c|}
\hline $\begin{array}{l}\text { Calcofluor } \\
\text { White Stain- } \\
\text { ing }\end{array}$ & $\begin{array}{l}\text { This test is used to detect cellulose in cell walls, } \\
\text { which fluoresces light blue under UV light (Figure } \\
\text { 1h) [19]. } \\
\text { 1. Place sections into } 0.01 \% \text { calcofluor white for } \\
10 \text { min. } \\
\text { 2. Rinse briefly in distilled water. } \\
\text { 3. Mount in distilled water. }\end{array}$ & \multirow[t]{3}{*}{$\begin{array}{l}\text { Sudan IV } \\
\text { Staining }\end{array}$} & $\begin{array}{l}\text { Sudan IV also stains lipids, in general [14], which } \\
\text { become red or red-orange (Figure } 2 \mathrm{~b} \text { ). } \\
\text { 1. Apply Sudan IV for } 30 \text { min. } \\
\text { 2. Rinse briefly in } 80 \% \text { ethanol. } \\
\text { 3. Wash in distilled water. } \\
\text { 4. Mount in glyceringelatin. }\end{array}$ \\
\hline \multicolumn{2}{|r|}{ Proteins } & & \multirow{2}{*}{$\begin{array}{l}\text { 5. Control: As with Sudan black B, the sections } \\
\text { should be kept in the extraction solution for at } \\
\text { least } 6 \mathrm{~h} \text {. }\end{array}$} \\
\hline \multirow{4}{*}{$\begin{array}{l}\text { Aniline Blue } \\
\text { Black Stain- } \\
\text { ing }\end{array}$} & \multirow{4}{*}{$\begin{array}{l}\text { This stain reveals proteins in blue (Figure } 1 \mathrm{i} \text { ) } \\
\text { [20], whether structural or acting in the primary } \\
\text { or secondary metabolism. } \\
\text { 1.. Dip sections into } 1 \% \text { aniline blue black for } 1 \\
\text { min. } \\
\text { 2. Wash twice in } 0.5 \% \text { acetic acid to remove ex- } \\
\text { cess stain. } \\
\text { 3. Rinse briefly in distilled water. } \\
\text { 4. Dehydrate sections passing quickly through } \\
90 \%, 100 \% \text { ethanol, then a mixture of } 100 \% \\
\text { ethanol and xylene }(1: 1, v / v) \text {, and finally pure } \\
\text { xylene. } \\
\text { 5. Mount slides using synthetic resin. } \\
\text { 6. Control: Put sections in a solution of acetic an- } \\
\text { hydride and pyridine }(4: 6, v / v) \text { for } 6 \mathrm{~h} \text { prior to } \\
\text { staining. }\end{array}$} & & \\
\hline & & $\begin{array}{l}\text { Neutral Red } \\
\text { Staining }\end{array}$ & $\begin{array}{l}\text { This fluorochrome emits different colors depend- } \\
\text { ing on the lipid composition [22]. Under blue } \\
\text { light, the lipids of secretion fluoresce yellow or } \\
\text { green (Figure 2f), cuticle fluoresces yellow and } \\
\text { lignified cell walls fluoresce red. } \\
\text { 1. Stain with } 0.1 \% \text { neutral red for } 20 \text { min. } \\
\text { 2. Rinse briefly in distilled water. } \\
\text { 3. Mount in distilled water. } \\
\text { 4. Control: As with Sudan black B, the sections } \\
\text { should be kept in the extraction solution for at } \\
\text { least } 6 \mathrm{~h} \text {. }\end{array}$ \\
\hline & & \multicolumn{2}{|c|}{ Acidic and Neutral Lipids } \\
\hline & & \multirow{2}{*}{$\begin{array}{l}\text { Nile Blue } \\
\text { Staining }\end{array}$} & $\begin{array}{l}\text { Since lipids were detected in the material, Nile } \\
\text { blue distinguishes acidic lipids, which stain blue, }\end{array}$ \\
\hline \multirow[t]{2}{*}{$\begin{array}{l}\text { Coomassie } \\
\text { Blue } \\
\text { Staining }\end{array}$} & \multirow[t]{2}{*}{$\begin{array}{l}\text { This method stains proteins blue (Figure } 1 \mathrm{j} \text { ) } \\
\text { [20] and produces a similar result to aniline blue } \\
\text { black. } \\
\text { 1. Stain in } 0.25 \% \text { Coomassie blue for } 15 \mathrm{~min} \text {. } \\
\text { 2. Differentiate in } 7 \% \text { acetic acid. } \\
\text { 3. Rinse briefly in distilled water. } \\
\text { 4. Mount in glyceringelatin. } \\
\text { 5. Control: Put sections in a solution of acetic an- } \\
\text { hydride and pyridine }(4: 6, \mathrm{v} / \mathrm{v}) \text { for } 6 \mathrm{~h} \text { prior to } \\
\text { staining. }\end{array}$} & & $\begin{array}{l}\text { from neutral lipids, which stain pink (Figure 2c) } \\
\text { [23]. } \\
\text { 1. Stain with Nile blue solution for } 5 \text { min at } 60^{\circ} \mathrm{C} \text {. } \\
\text { 2. Wash twice with } 1 \% \text { acetic acid at } 60^{\circ} \mathrm{C} \text {. } \\
\text { 3. Rinse in distilled water. } \\
\text { 4. Mount in glyceringelatin. } \\
\text { 5. Control: As with Sudan black B, the sections } \\
\text { should be kept in the extraction solution for at } \\
\text { least } 6 \mathrm{~h} \text {. }\end{array}$ \\
\hline & & \multicolumn{2}{|l|}{ Fatty Acids } \\
\hline \multicolumn{2}{|c|}{ Detection of Lipophilic substances } & \multirow{3}{*}{$\begin{array}{l}\text { Copper } \\
\text { Acetate and } \\
\text { Rubeanic } \\
\text { Acid } \\
\text { Staining }\end{array}$} & \\
\hline \multicolumn{2}{|c|}{ Lipids } & & than the Sudan tests and identifies fatty ac- \\
\hline \multirow[t]{2}{*}{$\begin{array}{l}\text { Sudan Black } \\
\text { Staining }\end{array}$} & \multirow{2}{*}{$\begin{array}{l}\text { This is a general method which stains lipids dark } \\
\text { blue to black (Figure } 2 \mathrm{a} \text { ) [14]. } \\
\text { 1. Stain with Sudan black B for } 20 \text { min. } \\
\text { 2. Rinse briefly in } 70 \% \text { ethanol. } \\
\text { 3. Wash in distilled water. } \\
\text { 4. Mount in glyceringelatin. } \\
\text { 5. Control: Sections should be kept in the extrac- } \\
\text { tion solution [21] for } 6 \mathrm{~h} \text { or more, depending on } \\
\text { the composition of the secretion (determined } \\
\text { empirically). After this time, the sections should } \\
\text { be transferred to distilled water and washed in } \\
\text { a period of } 4 \mathrm{~h}(4 \times 1 \mathrm{~h} \text { ). Then, the staining pro- } \\
\text { ceeds as described. }\end{array}$} & & $\begin{array}{l}\text { ids through the reaction of copper acetate with } \\
\text { these acidic lipids, which subsequently turn dark } \\
\text { green when exposed to rubeanic acid (Figure 2d) } \\
{[24,25]}\end{array}$ \\
\hline & & & $\begin{array}{l}\text { 1. Treat sections with } 0.05 \% \text { copper acetate for } \\
3 \mathrm{~h} \text {. } \\
\text { 2. Apply } 0.1 \mathrm{M} \mathrm{Na} 2 \text { EDTA (EDTA acid disodium } \\
\text { salt solution) for } 5 \mathrm{~min} \text {. } \\
\text { 3. Wash in distilled water for } 5 \mathrm{~min} \text {. } \\
\text { 4. Transfer sections into } 0.1 \% \text { rubeanic acid } \\
\text { (freshly prepared) for } 20 \text { min. } \\
\text { 5. Wash in } 70 \% \text { ethanol for } 5 \mathrm{~min} \text {. } \\
\text { 6. Rinse in distilled water. }\end{array}$ \\
\hline & & & $\begin{array}{l}\text { 7. Mount in glyceringelatin. } \\
\text { 8. Control: As with Sudan black B, the sections } \\
\text { should be kept in the extraction solution for at } \\
\text { least } 6 \mathrm{~h} \text {. }\end{array}$ \\
\hline
\end{tabular}




\begin{tabular}{|c|c|}
\hline \multicolumn{2}{|l|}{ Terpenes } \\
\hline $\begin{array}{l}\text { NADI } \\
\text { Reaction }\end{array}$ & $\begin{array}{l}\text { This reagent produces differential staining [26], } \\
\text { with essential oils (Figure 2e; monoterpenes and } \\
\text { sesquiterpenes) staining blue and resins (diter- } \\
\text { penes, triterpenes, tetraterpenes and deriva- } \\
\text { tives) staining red. Mixtures of essential oils and } \\
\text { resins produce varied shades of violet to purple, } \\
\text { depending on the prevalence of each compound. } \\
\text { 1. Apply NADI reagent for } 1 \mathrm{~h} \text { in the dark. } \\
\text { 2. Wash in sodium phosphate buffer }(0.1 \mathrm{M}, \mathrm{pH} \\
\text { 7.2) for } 2 \text { min. } \\
\text { 3. Mount in the same buffer. } \\
\text { 4. Control: As with Sudan black B, the sections } \\
\text { should be kept in the extraction solution for at } \\
\text { least } 6 \mathrm{~h} \text {. }\end{array}$ \\
\hline \multicolumn{2}{|c|}{ Detection of Phenolic Compounds and Alkaloids } \\
\hline \multicolumn{2}{|c|}{ Phenolic compounds } \\
\hline $\begin{array}{l}\text { Ferric } \\
\text { Chloride } \\
\text { Staining }\end{array}$ & $\begin{array}{l}\text { This method highlights phenolic compounds } \\
\text { through iron precipitation, producing a dark } \\
\text { color [12], usually black (Figure 3a), sometimes } \\
\text { brown. } \\
\text { 1. Apply } 10 \% \text { ferric chloride for } 30 \text { min. } \\
\text { 2. Wash twice in distilled water to remove sur- } \\
\text { plus ferric chloride. } \\
\text { 3. Mount in glyceringelatin. }\end{array}$ \\
\hline $\begin{array}{l}\text { Potassium } \\
\text { Dichromate } \\
\text { Staining }\end{array}$ & $\begin{array}{l}\text { This method also highlights phenolic compounds; } \\
\text { in general [27], producing a brown or red-brown } \\
\text { color (Figure 3b). } \\
\text { 1. Apply } 10 \% \text { potassium dichromate for } 30 \text { min. } \\
\text { 2. Wash twice in distilled water to remove sur- } \\
\text { plus reagent. } \\
\text { 3. Mount in glyceringelatin. }\end{array}$ \\
\hline
\end{tabular}

Ferrous Sul- The best method to detect phenolic compounds is fate-Forma- to introduce iron salts into the fixative since the lin Fixation iron compound fixes and stains the phenolic compounds (Figure 3c) [12].

1. The samples should be fixed in the ferrous sulfate-formalin solution under vacuum for $48 \mathrm{~h}$.

2. Wash $4 \times 2 \mathrm{~h}$ (totaling $8 \mathrm{~h}$ ) in distilled water.

3. Dehydrate the material in $30 \%, 50 \%, 70 \%$ ethanol for $12 \mathrm{~h}$ each.

4. Embed the material according to the chosen technique (Paraplast, Historesin, or PEG) and then section in a microtome

\begin{tabular}{l|l} 
Vanillin- & This test is more specific for some phenolic com-
\end{tabular} Hydrochlo- $\quad$ pounds, staining tannins red (Figure 3d) [28]. ric Acid Staining for Tannins Use only sections of fresh material.

1. Treat with $0.5 \%$ vanillin for $20 \mathrm{~min}$.

2. Mount the slide using $9 \%$ hydrochloric acid.

\begin{tabular}{l|l} 
Phloroglu- & Phloroglucinol in an acidic medium stains lignin
\end{tabular} cinol-Hy- $\quad$ in cell walls pink to red (Figure 3e) [12]. It is posdrochlo- $\quad$ sible to use either fresh or embedded material.

ric Acid Stainingfor Lignin
1. Apply $10 \%$ phloroglucinol for 15 min.

2. Mount the slides carefully with $25 \%$ hydrochloric acid.

\begin{tabular}{|c|c|}
\hline $\begin{array}{l}\text { Acridine } \\
\text { Orange }\end{array}$ & $\begin{array}{l}\text { This fluorescent dye is useful to identify several } \\
\text { acidic compounds under blue light, such as nu- } \\
\text { cleic acids and components of the cell wall [29], } \\
\text { distinguishing lignified cell walls (yellow-green } \\
\text { fluorescence) from non-lignified cell walls (red } \\
\text { fluorescence; Figure } 3 g \text { ). It is possible to use } \\
\text { fresh material as well as embedded material in } \\
\text { this test. } \\
\text { 1. Apply } 0.01 \% \text { acridine orange for } 20 \text { min. } \\
\text { 2. Mount the slides with distilled water. }\end{array}$ \\
\hline & $\begin{array}{l}\text { Plant tissues have several autofluorescent com- } \\
\text { ponents which permit their analysis under UV ra- } \\
\text { diation [30]. In relation to secondary metabolites, } \\
\text { many phenolic compounds (including lignin) } \\
\text { emit a blue or blue-green fluorescence (Figure } \\
1 \mathrm{~g}, 3 \mathrm{f} \text { ). } \\
\text { However, it is necessary to be cautious in iden- } \\
\text { tifying compounds through autofluorescence } \\
\text { because some alkaloids and terpenoids may also } \\
\text { emit fluorescence in the blue band [32]. }\end{array}$ \\
\hline \multicolumn{2}{|l|}{ Alkaloids } \\
\hline $\begin{array}{l}\text { Dragen- } \\
\text { dorff's } \\
\text { Reagent }\end{array}$ & $\begin{array}{l}\text { This reagent marks alkaloids in red-brown (Fig- } \\
\text { ure 3h) [31]. Fresh and fixed material may be } \\
\text { used in this method, but fixed material shows a } \\
\text { considerably loss of the alkaloids and the staining } \\
\text { color when compared to fresh material. } \\
\text { 1. Treat with Dragendorff's reagent for } 20 \text { min. } \\
\text { 2. Rinse briefly in } 5 \% \text { sodium nitrite. } \\
\text { 3. Mount in distilled water. } \\
\text { 4. Control: Treat sections with } 5 \% \text { tartaric acid } \\
\text { in } 95 \% \text { ethanol for } 72 \mathrm{~h} \text { and repeat the staining } \\
\text { procedure. }\end{array}$ \\
\hline $\begin{array}{l}\text { Wagner's } \\
\text { Reagent }\end{array}$ & $\begin{array}{l}\text { This method also stains alkaloids red or red- } \\
\text { brown (Figure 3i) [32]. It is recommended that } \\
\text { fresh material be used for this test. } \\
\text { 1. Apply Wagner's reagent for } 20 \mathrm{~min} \text {. } \\
\text { 2. Rinse briefly in distilled water. } \\
\text { 3. Mount in distilled water. } \\
\text { 4. Control: Treat sections with } 5 \% \text { tartaric acid } \\
\text { in } 95 \% \text { ethanol for } 72 \mathrm{~h} \text { and repeat the staining } \\
\text { procedure. }\end{array}$ \\
\hline
\end{tabular}

Table 1: Some stains that are commonly used in histochemical tests.

\section{Applications of histochemistry in plant research}

In detection and localization of secondary metabolites in certain medicinal plants

Histochemical study was carried out to localize polyphenolic terpenoid aldehydes and fixed oil in healthy seeds, stems, leaves and roots of Gossypium barbadense L. var. Giza 86. In all examined organs, polyphenolic terpenoid aldehydes and fixed oil were mainly detected inside lysigenous glands. In young leaves and roots, polyphenolic aldehydes were also observed as fine particles inside 


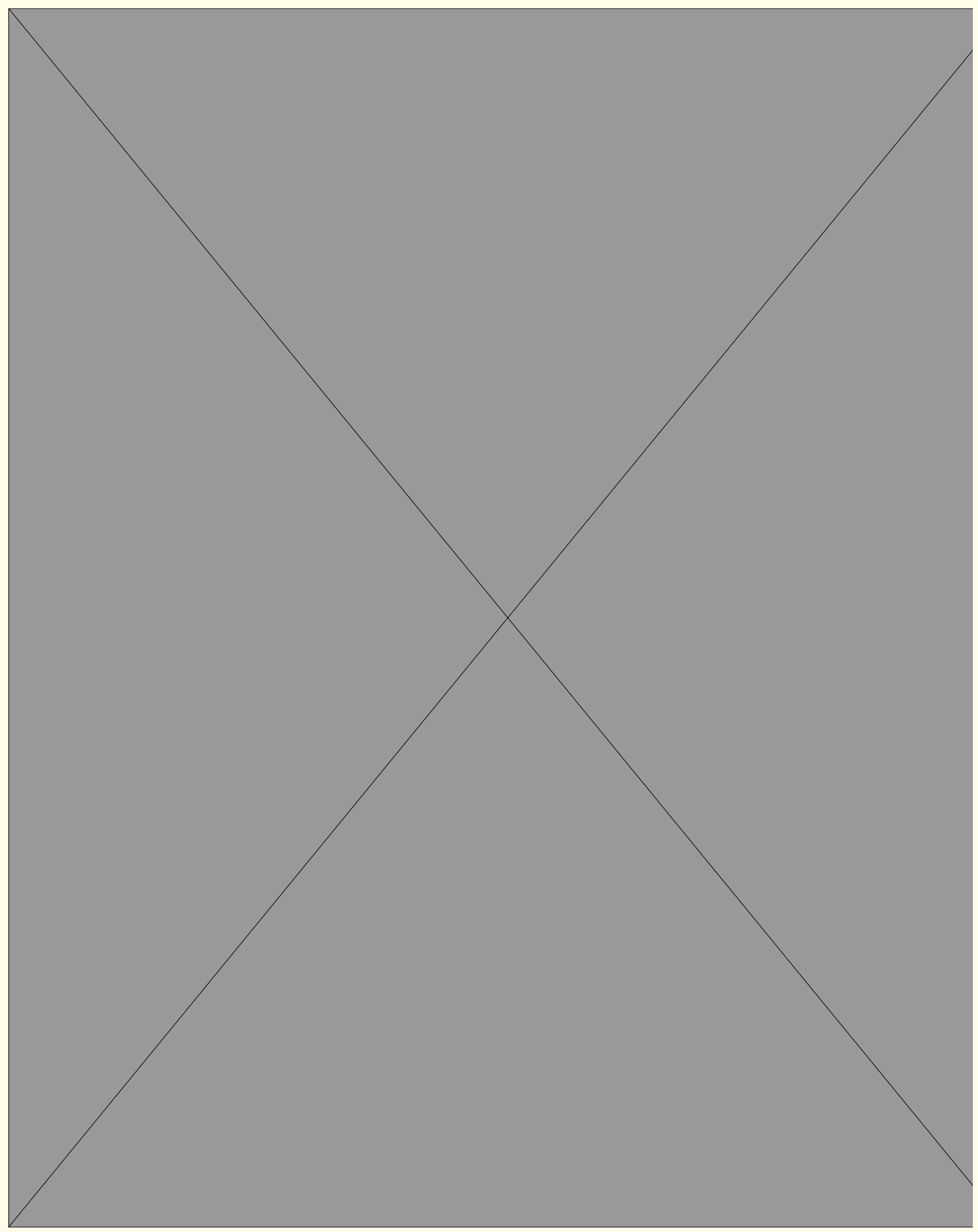

Figure 1: Histochemical analysis of 1 structures. (a, c, g-i) Embedded material. (b, d-f, j) Fresh material. (a) Detection of acidic mucilage in the colleter of Asclepiascurassavica L. (Apocynaceae) by ruthenium red. (b) Identification of acidic mucilage in the epidermis of Rhododendron sp. (Ericaceae) by Alcian Blue. (c) Positive result for mucilage in secretory idioblast of Cattleyawalkeriana Gardner (Orchidaceae) using tannic acid and ferric chloride. (d) Starch grains in the nectary of Inga edulis Mart. (Fabaceae) detected by Lugol's reagent. (e) Observation of starch grains in laticifer of Euphorbia miliiDes Moul. (Euphorbiaceae) and the tissue structure using the triple staining. (f) Detection of carbohydrates in the secretory idioblast of Ceibaspeciosa [7]. 


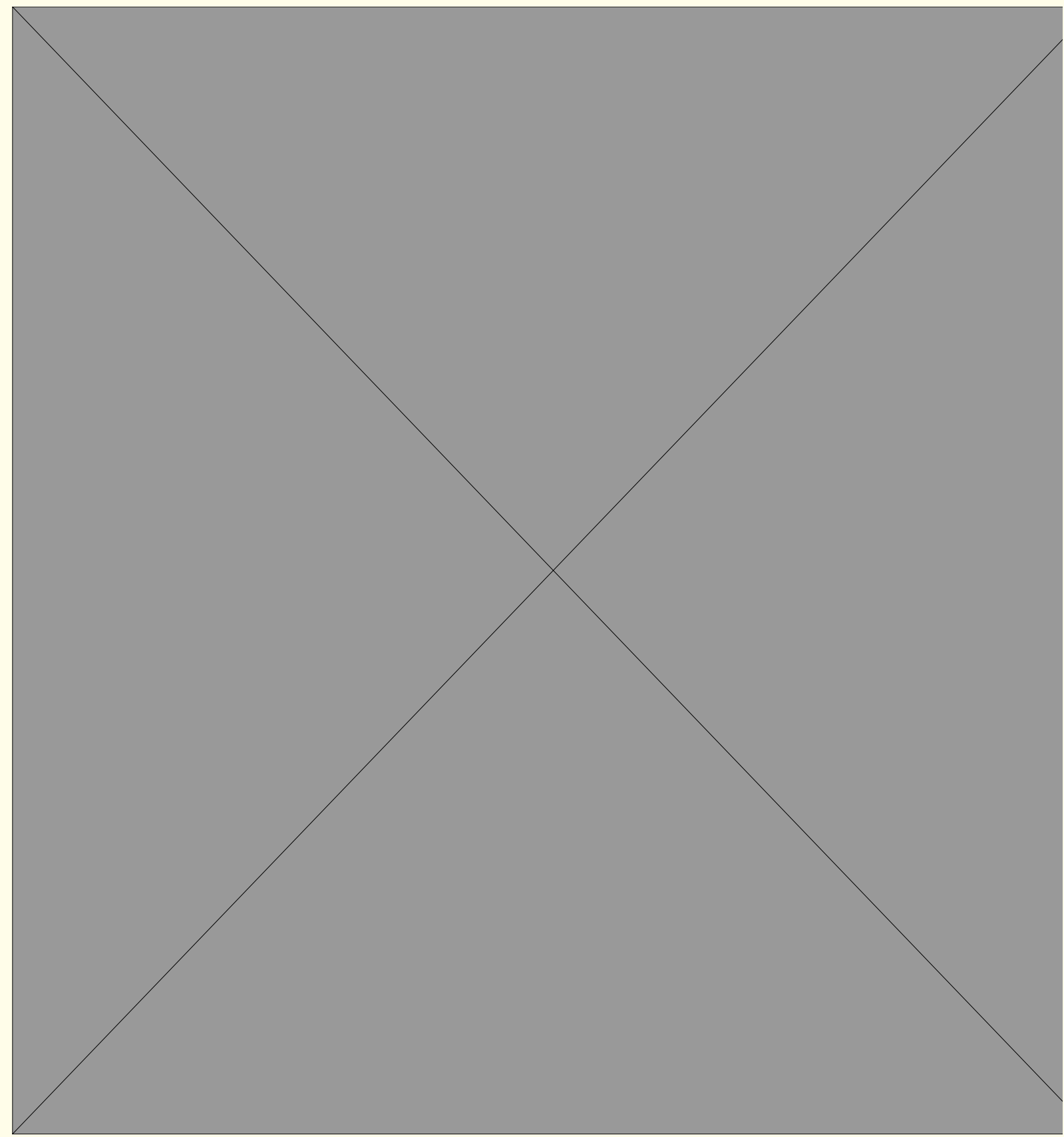

Figure 2: Histochemical analysis of plant secretory structures. Fresh material. (a) Detection of lipids production by elaiophore of Byrsonima intermedia A. Juss. (Malpighiaceae) by Sudan black B. (b) Identification of lipids in the secretory duct of Philodendron sp. (Araceae) by Sudan IV. (c) Positive result for neutral lipids in the laticifer of Sapiumglandulatum (Vell.) Pax (Euphorbiaceae) by Nile blue. (d) Observation of fatty acids in the glandular trichome of Tetradeniariparia (Hochst.) Codd (Lamiaceae) using copper acetate and rubeanic acid. (e) Detection of essential oils in the secretory idioblasts of Peploniaaxillaris(Vell.) Fontella and Rapini (Apocynaceae) by NADI reagent. (f) Identification of lipids in secretory duct of Kielmeyeraappariciana Saddi (Calophyllaceae) by neutral red under blue light. (g) Positive result for lipids in glandular trichome of Tetradeniariparia by Nile blue under blue light [7]. 


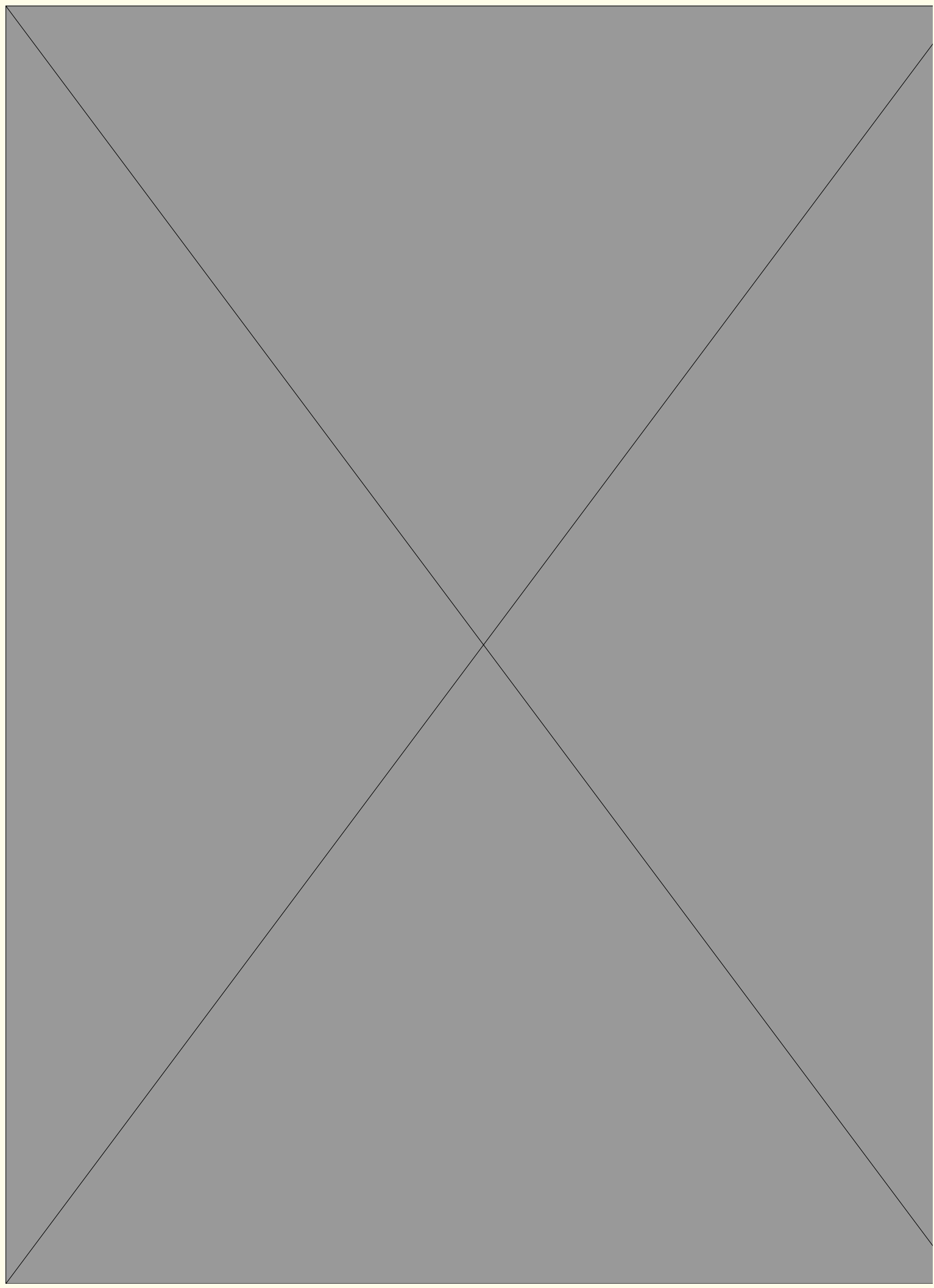

Figure 3: Histochemical analysis of plant secretory structures. (a, b, d, f-i) Fresh material. (c, e) Embedded material. (a-c) Detection of phenolic compounds in secretory idioblasts. (a) Ferric chloride. Acalyphaamentacea Roxb. (Euphorbiaceae). (b) Potassium dichromate. Calliandrat weediei Benth. (Fabaceae). (c) Ferrous sulfate in formalin [7]. 
the cytoplasm of some parenchymatous cells around glands. Lysigenous terpenoid-containing glands were noticed in all tap root regions except the apical $3 \mathrm{~cm}$. The number of glands increased with increasing distance from the root tip. This may explain why the antimitotic activity of gossypol does not affect the growing tip of the plant [33].

Three species used in folk medicine were choosen to determine their histochemical investigation: Adhatod azeylanica, Ruta graveolence and Vitex negundo. In general, these plants are used in folkmedicine in the treatment of gonorrhoea, antiperiodic, bronchitis, infected wounds, scrotal swelling, synovitis, arthritis pain and rheumatic arthritis. For histochemical studies the free hand sections of leaves and stem were taken and treated with the respective reagent to localize components, viz. starch, protein, tannin, saponin, fats, glucosides and alkaloids in the tissues [34].

A histochemical analysis of leaf and rhizome of Curcuma neilgherrensis was done. The study revealed the identification and location of the phytochemicals like alkaloids, saponins, tannins, oils, starch grains etcin various regions of leaf and rhizome of C. neilgherrensis. Free hand sections were taken and treated with respective reagents to localise the various cellular components. The observations could be of great use in chemotaxonomy and checking the drug adulteration [35].

Furthermore, the histochemical studies of leaves and wood of Sesbania grandiflora, Sesbaniabi spinosa and Sesbania cannabina are medicinally important plants of Marathwada region in Maharashtra. For histochemical studies the free hand sections of leaves and wood were taken and treated with the respective reagent in localize components, viz. starch, protein, tannin, saponin, fat, glucosides and alkaloids in the tissues [36].

Solidago chilensis Meyen, belonging to the family Asteraceae, is a plant native to South America and the only representative of the genus in Brazil. This species is popularly known as "arnica" and is used to treat bruises, muscle pain and inflammation. Cross-sections were obtained, by freehand, for microscopic analysis of root, stem and leaf; for these parts of the plant maceration was also performed according to the method of Jeffrey. For the leaf were still made paradermal sections, scanning electron microscopy analysis, phytochemical and histochemical tests. Thus, it was determined anatomical features useful for diagnosis of the species which, together with identification of the chemical compounds and its histo localization, provides support to their quality control [37].

Carbohydrate storage in the form of starch grains has been examined in stems and roots of Jatropha curcas. The predominant starch-storing tissues were identified, and the cellular localization of the starch grains within these tissues was determined. In stem sections, starch was seen predominantly in parenchymatous cortex, medullary rays, pith while in the root sections, starch was seen highly concentrated only in cortical tissues and to some extent as brownish black patches in the medullary rays [38].

Thymus quinqueco status, with more medical value, is a kind of wild plants. In order to exploit and utilize this plant, we studied the species and locations of alkaloids in its leaves. A histochemical study of leaves at different developing stages was taken to localize the alkaloids. Meanwhile, the kinds and content of alkaloids in leaves were identified using GC-MS technique. It was found that there were two kinds of glandular trichomes, namely, peltate trichomes and capitate trichomes, on the surface of leaves, and their secretory cells could secrete alkaloids. Results showed that trichomes could secrete alkaloids as soon as the first pair of leaves formed, and there were altogether 18 kinds of alkaloids identified by GC-MS. Nearly all of these alkaloids of leaves at different developing stages were distinct from each other, except one, 3-methoxya-methyl-benzeneethanamine, persists at different developing stages with high concentration [39].

Studies on the phytochemical profiling and histochemical localization in leaf and stem of Trichosanthes cucumerina (L) var. cucumerina with reference to the influence of plant age and geographical variations were carried out using Wagner's reagent concluded that alkaloids are mostly located in the parenchyma cells bordering the vascular bundles of stem and petiole. Flavonoids, localized with $\mathrm{NaOH}$ revealed that they were marked as a distinct yellow band in the sub hypodermal layer of stem. Tannin localization with $\mathrm{FeCl} 3$ also suggested their storage in parenchyma cells [40].

Studies on the phytochemical profiling and histochemical localization in leaf and stem of Trichosanthes cucumerina (L) var. cucumerina with reference to the influence of plant age and geographical variations were carried out using Wagner's reagent concluded that alkaloids are mostly located in the parenchyma cells bordering the vascular bundles of stem and petiole. Flavonoids, localized with $\mathrm{NaOH}$ revealed that they were marked as a distinct yellow band in the sub hypodermal layer of stem. Tannin localization with $\mathrm{FeCl} 3$ also suggested their storage in parenchyma cells [40].

An evaluatation of the histochemistry of the leaf blade of Byrsonimaverbascifolia (L.) DC., Malpighiaceae, Cam-pomanesiaadamantium (Cambess.) 0. Berg, Myrtaceae, Roupalamontana Aubl., Proteaceae, and Solanumlycocarpum A. St.-Hil., Solanaceae, species that have been reported as producers of secondary metabolites for pharmacological use was performed.

Tests were conducted for lipids, terpenoids, phenolic compounds, alkaloids, sugars and proteins. Alkaloids were observed only in R. montana, as well as the results for phenolic compounds. Flavonoids are present in B. verbascifolia and $R$. montana. The lipid composition was showed for the chemical compounds of $B$. verbascifolia and $C$. adamantium, which proved to be part of the es- 
sential oils or resins oils in $C$. Adamantium idiolects. The chemical compounds of B. verbascifolia, $C$. adamantium and $R$. montana are present mainly in idioblasts among the parenchyma and epidermal cells. C. adamantium has secretory cavities, but only with lipid content [41].

The genus Barleria lupulina Lindl of the family Acanthaceae belongs to the sub tribe Barlerieae of the tribe Justicieaesensu Benth and Hook. An investigation mainly emphasized on the histochemical localization of phytochemicals like alkaloids, starch, tannins, reducing sugars, proteins, flavonoids, amino acids and lignins. The active compounds were identified prominently in different locations of the stem, leaf petiole and root of the medicinal plant $B$ lupulina under study. It was found that presence of number of phytochemicals in xylem is higher than other tissues [42]

Histochemical localization of starch, protein, lipid and lignin in the callus, field-grown and in vitro raised plants

Scopariadulcis L. (Scrophulariaceae), commonly known as bitter broom or kallurukki, is much valued in tradition medicine to treat respiratory, gastric and hepatic disturbances, kidney stones, diabetes and inflammations. Histochemical localization of starch, protein, lipid and lignin was done in the calli and regenerated plants of S. Dulcis grown in MS medium supplemented with $0.1 \mathrm{mg} / \mathrm{l}$ IBA, and also in the field-grown plants. Starch grains were abundant in the cortex and pith of field-grown plants and also in the calli, while the in vitro raised plants had lesser starch content. Intense accumulation of proteins was observed in the calli and in vitro raised plants. Both the field-grown and in vitro raised plants showed accumulation of lipids in the cortex and pith, and heavy deposition of lignin in the xylem elements. The calli showed a greater deposition of starch, proteins, lipids and lignin, when compared to both the field-grown as well as in vitro raised plants. The study reveals the potential of utilizing calli in herbal formulations of the species, as this may yield better results including improved nutraceutical value [43].

In the supposed defense mechanism actions (Parasitic plant host - root interaction)

Roots of different hosts of the holophrastic weed known as broomrape (Orobanche spp.) were examined histochemicaly for the occurrence of structural cellular barrier formation following wounding/penetration. Such barrier might function to impede the successful development of parasite haustorium interaction, i.e. as a self defence mechanism. In faba bean and white bean, brown deposits occurred in walls adjacent to the damaged cells of the epidermis, cortex and stele. Via stain reactions and colorations these deposits were detected as melanin. Additionally, walls bordering damaged site at the level of the endodermis and within the stele becomes uberized and lignified. In peas, which possesses a lignified hypodermis, the response was similar but lignin was also de- posited in the walls of the endodermis and hypodermis adjacent to the wound. In sunflower, which possesses a suberized hypodermis, melanin was deposited in the hypodermis and lignin and suberin occurred within the stele. In all these broomrape host species melanization conferred the modified cell wall many of the properties associated with lignified and suberized structures such as impermeability and resistance to chemical degradation [44].

In detection of active substances in aromaticplant; citral accumulation in lemongrass

The sites of citral accumulation in lemongrass (Cymbopogon flexuosus Nees ex Steud) wats (cultivar OD-19) were located by Schiff'sreagent, which upon its reaction with aldehydes (citral) gives a purple-red colouration. Using this technique, single oil-accumulating cells were detected in the adaxial side of leaf mesophyll commonly adjacent to non-photosynthetic tissue and between vascular bundles. In this respect, however, the citral lacking cultivar GRL-1 (geraniol rich) leaf sections, which also was subjected to Schiff's reagent could be compared to the cultivar OD-19 leaf sections. In lemongrass mutant GRL-1, those specialized cells, however, are not being stained due to lack of citral. Hence, it could be confirmed that the observed schiff's staining reaction is associated with the accumulation of citral substance in a given cell [45].

\section{New applications}

In localization of the site of monoterpene phenols accumulation in plant secretory structures

A new method is reported for the histochemical localization of monoterpene phenols in essential oil secretory structures. The method was adapted from a spot test originally devised for in vitro detection of phenolic compounds in organic analyses. Plant subjects were the Lamiaceae species Thymus vulgaris L., Oreganum vulgare L. and Mentha x piperita L., which accumulate essential oil in glandular trichomes. A reagent consisting of 4-nitrosophenol in conc. $\mathrm{H}_{2} \mathrm{SO}_{4}$ was applied to sample leaves of each species. A positive test for phenol was indicated by the production of coloured indophenols. Using this method, monoterpene phenols were identified in the trichomes of T. vulgaris (thymol) and 0 . vulgare (carvacrol), indicated by colour changes to red and green respectively [46].

Detection of cytokinins and auxin in plant tissues using histochemistry and immunocytochemistry

A new method for histochemical localization of cytokinins (CKs) in plant tissues based on bromophenol blue/silver nitrate staining was reported. The method was validated by immunohistochemistry using anti-trans-zeatin riboside antibody. Indole-3-acetic acid (auxin, IAA) was localized byanti-IAA antibody in plant tissues as a proof for IAA histolocalization. Root sections were used, because they are major sites of CKs synthesis, and insect galls of Piptadeniagonoacantha that accumulate IAA. Immunostaining confirmed the presence of zeatin and sites of accumulation of IAA indicated 
by histochemistry. The colors developed by histochemical reactions in free-hand sections of plant tissues were similar to those obtained by thin layer chromatography (TLC), which reinforced the reactive sites of zeatin. The histochemical method for detecting CKs is useful for galls and roots, whereas IAA detection is more efficient for gall tissues. Therefore, galls constitute a useful model for validating histochemical techniques due to their rapid cell cycles and relatively high accumulation of plant hormones [47].

\section{Locating enzymes in plant tissue using nitrocellulose blotting}

The blotting of fresh tissue sections onto nitrocellulose and the detection of enzyme activities on the blots for polyphenol oxidase, peroxidase, glycosidases, dehydrogenase and phosphatase activity has been shown successfully using a simple histochemical method. Two cm squares of nitrocellulose membrane filters B A 28, (Schleicher and Schüll, $0.45 \mu \mathrm{m}$ pore size) were soaked in distilled$\mathrm{H}_{2} \mathrm{O}$, placed on microscope slides and blotted dry with a tissue. A2$3 \mathrm{~mm}$ section through the plant tissue was placed on the membrane and then lightly pressed on it using an additional microscope slide. The section was removed carefully and the membrane thoroughly rinsed with distilled $\mathrm{H}_{2} \mathrm{O}$ to remove non-proteinaceous material or soluble compounds and lightly pressed with a tissue to remove excess water. About $0.2 \mathrm{ml}$ of the appropriate substrate or reagent was next spread over the surface of the membrane. The slides were incubated in a moist atmosphere for the reaction to proceed, the substrate was then rinsed off, and if necessary a developing reagent added. For fast reactions with immediate colour production the substrate wasadded and rinsed off as soon as colour development was optimal e.g. polyphenol oxidase or peroxidase. Alternatively the nitrocellulose blot can be placed (blot side upwards) on to a piece of filter paper moistened with substrate. This gives very good resolution and localization of enzyme activity [48].

\section{In gene expression}

The detection of plant transformation (using $\beta$-glucuronidase; GUS assay in Lilium are carried out via the application of histochemical methods. $\beta$-glucuronidase (GUS) assay is used to assess transient expression of the GUS gene using 5-bromo-4-chloro-3-indolyl $\beta$ D-glucuronide (X-Gluc) as the substrate. Six days after cocultivation, samples of $0.1 \mathrm{~g}$ of callus collected from each treatment are subjected to transient histochemical GUS assay. The transformation efficiency of calli are evaluated by counting the number of blue spots, using stereo microscope, showing GUS enzyme activity on each callus sample [49]. The methods/technique are described by Azadi., et al. [50].

The use of the histochemical methods in iron and ferritin gene expression in transgenic indica rice (Oryza sativa L. Cv Pusa basmati) proved as efficient in such an investigation. Perl's Prussian blue stainingof transgenic rice grain sections show distribution of iron accumulation (blue compound of ferricferrocyanide) through- out the allure one and sub aleurone layers and in the central region of thestarchy endosperm. Whereas, in the nontransgenic grains, blue colour formation indicating iron accumulation was restricted to the aleurone layer and the intensity of color was also very low. Transverse section of the transgenic rice grains indicated the high iron accumulation in embryo as well as in the endosperm, in comparison to the non transgenic ones. In the latter, iron appeared restricted to the embryo and aleurone layer in which the intensity of color detected in the embryo was verylow. This histochemical analysis of iron in rice specifically showed temporal and spatial deposition of storage iron [51].

Advances in histochemistry and cytochemistry made are possible to retrieve quantitative data from 2Dand 3D microscopic images. In this way, valid quantitative results can be regenerated (e.g. gene expression data at the mRNA, protein and activity levels) from microscopic images in relation to structures in cells, tissues and organs in 2D and 3D.Volumes, areas, lengths and numbers of cells and tissues can be calculated and related to these gene expression data while preserving the 2D and 3Dmorphology [52].

In detection of heavy metals, i.e. pollution and contamination Heavy metals accumulation

Histochemical methods were employed in the detection of the heavy metals $(\mathrm{Cd}, \mathrm{Pb}, \mathrm{Ni}$, and $\mathrm{Zn})$ andstrontium, their distribution, accumulation, and translocation within the tissues of higher plants. In this respect, detailed protocols of metal detection with metallochrome indicators dithizone $(\mathrm{Cd}, \mathrm{Pb})$, dimethylglyoxime $(\mathrm{Ni})$, sodium rhodizonate(Sr), zincon $(\mathrm{Zn})$, and fluorescent indicator Zinpyr_1(Zn) by light and fluorescence microscopy were described [53].

The occurrence of heavy metals and their accumulation in water hyacinth [Eichhorniacrassipes (Mart.) Solms] was investigated. The histochemical staining examinations indicated the accumulation in the epidermis and vascular bundles of the roots and petiole. In the leaf sections the palisade tissues were deeply stained, showing the high accumulation of the metals within the leaves [54].

In detection of $\mathrm{H}_{2} \mathrm{O}_{2}$ and $\mathrm{O}_{2}-$; a result of cadmium contamination

The effect of cadmium on $\mathrm{H}_{2} \mathrm{O}_{2}$ and $\mathrm{O}_{2} \cdot-$ production in leaves from pea plants grown for 2 weeks with $50 \mu \mathrm{m} \mathrm{Cd}$, by histochemistry with diaminobenzidine (DAB) and nitro blue tetrazolium (NBT), respectively was studied. The subcellular localization of the reactive oxygen species(ROS) was studied by using $\mathrm{CeCl}_{3}$ and $\mathrm{Mn}$ / DAB staining for $\mathrm{H}_{2} \mathrm{O}_{2}$ and $\mathrm{O}_{2} \cdot-$, respectively, followed by electron microscopy observation. In leaves from pea plants grown with 50 $\mu \mathrm{m} \mathrm{CdCl}{ }_{2}$, a rise of six times in the $\mathrm{H}_{2} \mathrm{O}_{2}$ content took place in comparison to control plants. The accumulation of $\mathrm{H}_{2} \mathrm{O}_{2}$ was localized mainly in the plasma membrane, mesophyll and epidermal cells, as 
well as in the tonoplast of bundle sheath cells. In mesophyll cells, the accumulation of $\mathrm{H}_{2} \mathrm{O}_{2}$ was observed in mitochondria and peroxisomes. Localization of $\mathrm{O}_{2} \cdot-$ production was demonstrated in the tonoplast of bundle sheath cells, and plasma membrane from mesophyll cells. The Cd-induced production of the ROS, $\mathrm{H}_{2} \mathrm{O}_{2}$ and $\mathrm{O}_{2} \cdot-$, could beattributed to the phytotoxic effect of $\mathrm{Cd}$. In this connection, lower levels of ROS were assumed tofunction as signal molecules for the induction of defense genes against the injurious effects of the heavy metal [55].

However, Jin., et al. found that exposure to cadmium resulted in significant ultra structure changes in the root meristems and leaf mesophyll cells of Sedum alfredii Hance. Damages were more pronounced in NHE (non-hyperaccumulator ecotypes) even when Cd concentrations were one-tenth of those applied to HE (hyperaccumulator ecotypes). In the cadmium stress damaged chloroplasts resulted in imbalanced lamellae formation which is coupled with early leaf senescence. Histochemical results revealed that glutathione (GSH) biosynthesis inhibition led to overproduction of hydrogen peroxide $\left(\mathrm{H}_{2} \mathrm{O}_{2}\right)$ and superoxide radical $\left(\mathrm{O}_{2}^{-}\right)$in HE but not in NHE. The GSH biosynthesis induction in root and shoot exposed to elevated Cd conditions, however, might be involved in Cd tolerance and hyper accumulation in HE of S. alfredii $\mathrm{H}$ [56].

In the detection of aluminum accumulation, lipid peroxidation, callose production, and plasma membrane integrity

In peas (Pisumsativum L.) roots, staining were observed to distribute similarly on the entire surface of the root apex regarding aluminum accumulation, lipid peroxidation, and callose production).Meanwhile, the loss of plasma membrane integrity (detected by Evans blue uptake) was localized exclusively at the periphery of the cracks on the surface of root apex. The enhancement of four phenomena, i.e. aluminium accumulation, lipid peroxidation, callose production and root elongation inhibition displayed similar aluminum dose dependencies which occurred at $4 \mathrm{hrs}$ exposure. The loss of membrane integrity, however, was enhanced at lower aluminum concentrations and after a longer aluminum exposure of 8hrs. The addition of butylatedhydroxyanisole (a lipophilic antioxidant) during aluminum treatment was found to completely prevent only the lipid peroxidation and callose production by $40 \%$. Thus, lipid peroxidation was suggested to represent relatively early symptom induced by the accumulation of aluminum and appear to cause, in part, callose production. Whereas, the loss of plasma membrane integrity represented a relatively late symptom caused by cracks in the root is due to the inhibition of root elongation [57].

\section{Conclusion}

Many plants contain medicinally important secondaryproducts. Therefore, histochemical investigations of different plant parts dealing with theidentification of chemical components of cells and tissues. Furthermore, histochemical localization has numerous and unique economic and pharmaceutical implications. Based on the investigation, this review concludes that histochemical localization could be used ina rapid field survey to identify the existence ofbioactive compounds in certain plants.

\section{Bibliography}

1. Kadam V B. "Histochemical investigations of different organs of three Endangered medicinal taxa of South Gujarat Forests". Journal of Phytological Research 12 (1999): 109-112.

2. Kuster E. "Die pflanzenzelle", 3rd ed, Jene Gustav Fischer verlag, Jena (1956): 232.

3. Kadam V B., et al. "Nutritional status of seeds of some tree species". Journal of Environmental Biology 5 (1996): 96-98.

4. Seifriz W. “Protoplasm Mac Graw Hill Book Company”. Inc. New York (1936).

5. Dhar M L., et al. "Screening of Indian Plants for Biological Activity-Part I". Indian Journal of Experimental Biology 6.4 (1968): 232-247.

6. Wick M R. "Histochemistry as a tool in morphological analysis: A historical review". Annals of Diagnostic Pathology 16.1 (2012): 71-78.

7. Demarco D. "Histochemical Analysis of Plant Secretory Structures”, chapter 24, Carlo, P. and Marco, B. (eds.), Histochemistry of Single Molecules: Methods and Protocols, Methods in Molecular Biology. 1560 (2017).

8. Coleman R. "The impact of histochemistry - a historical perspective". Acta Histochemica 102.1 (2000): 5-14.

9. Fahn A. "Secretory tissues in vascular plants". New Phytology 108.3 (1988): 229-257.

10. Evert R F. "Esau's plant anatomy". 3rdedn.,John Wiley \& Sons, Hoboken, NJ (2006).

11. Demarco D. “Micromorfología y histoquímica de loslaticíferos de órganosvegetativos de especies de Asclepiadoideae (Apocynaceae)". Acta Biológica Colombiana 20.1 (2015): 57-65.

12. Johansen D A. "Plant microtechnique." McGraw-Hill, New York (1940).

13. Gregory M and Baas P. "A survey of mucilage cells in vegetative organs of the dicotyledons". Israel Journal of Botany 38 (1989): 125-174.

14. Pearse A G E. "Histochemistry: theoretical and applied". 2 4th ed., C. Livingstone Edinburgh (1985). 
15. Pizzolato T D. “Staining of Tiliamucilages with Mayer's tannic acid-ferric chloride". Bulletin of the Torrey Botanical Club 104.3 (1977): 277-279.

16. Demarco D., et al. "Two laticifer systems in Sapiumhaematospermum- new records for Euphorbiaceae". Botany 91 (2013): $545-554$.

17. McManus J F A. "Histological and histochemical uses of periodic acid". Stain Technology 23.3 (1948): 99-108.

18. Smith M M and McCully M E. "A critical evaluation of the specificity of aniline blue induce fluorescence". Protoplasma 95.3 (1978): 229-254.

19. Hughes J and McCully M E. "The use of an optical brightener in the study of plant structure". Stain Technology 50.5 (1975): 319-329.

20. Fisher D B. "Protein staining of ribbonedepon sections for light microscopy". Histochemistry 16.1 (1968): 92-96.

21. High O B. "Lipid histochemistry". Oxford University Press, New York, NY (1984).

22. Kirk P W. "Neutral red as a lipid fluorochrome". Stain Technology 45 (1970): 1-4.

23. Cain A J. "The use of Nile Blue in the examination of lipids". Quarterly Journal of Microscopical Science 88 (1947): 383-392.

24. Ganter P and Jollés G. "Histochimienormaleetpathologique, vol 1. Gauthier-Villars, Paris”. (1969).

25. Ganter P and Jollés G. "Histochimienormaleetpathologique, vol 2. Gauthier-Villars, Paris (1970).

26. David R and Carde J P. "Coloration différentielle des inclusions lipidique et terpeniques des pseudophylles du Pin maritime au moyen du reactifNadi". Comptes rendus de l'Académie des Sciences 258 (1964): 1338-1340.

27. Gabe M. "Techniques histologiques". Masson \& Cie, Paris (1968).

28. Mace M E and Howell C R. "Histochemistry and identification of condensed tannin precursor in roots of cotton seedlings". Canadian Journal of Botany 52.11 (1974): 2423-2426.

29. Ruzin S E. "Plant microtechnique and microscopy”. Oxford University Press, New York, NY (1999).

30. Talamond P., et al. "Secondary metabolite localization by autofluorescence in living plant cells". Molecules 20.3 (2015): 5024-5037.
31. Svendsen A B and Verpoorte R. "Chromatography of alkaloids. Elsevier Scientific Publishing Company, New York, NY (1983).

32. Furr M and Mahlberg P G. "Histochemical analyses of laticifers and glandular trichomes in Cannabis sativa". Journal of Natural Products 44.2 (1981): 153-159.

33. Badria F A., et al. "Histochemical Localization Of Polyphenolic Aldehydes In Gossypium Barbadense". International Journal of Research in Pharmaceutical and Nano Sciences 7.5 (2018): 200-204.

34. Dhale D A. "Histochemical investigation of some medicinal plants". ARPB 1.2 (2011): 147-154.

35. Nissar A R., et al. "Histochemical Studies of Curcuma Neilgherrensis-An Antidiabetic Herb”. WJPR 3.9 (2014): 731-741.

36. Momin R K and Kadam V B. "Histochemical investigation of different organce of genus sesbania of marathwada region in Maharashtra". Journal of Phytology 3.12 (2011): 31-34.

37. Douglas M F., et al. "Anatomical, phytochemical and histochemical study of Solidagochilensis Meyen". Annals of the Brazilian Academy of Sciences 90.2 (2018): 2107-2120.

38. Kumari V., et al. "Histochemical localization of starch in stem and root of Jatropha curcas (Euphorbiaceae)". Bulletin of Environment, Pharmacology and Life Sciences 7.4 (2018): 7-10.

39. Jing H., et al. "Histochemical Investigation and Kinds of Alkaloids in Leaves of Different Developmental Stages in Thymus quinquecostatus". The Scientific World Journal (2014): 1-6.

40. Aryakrishna U K., et al. "Phytochemical profiling and histochemical localization in leaf and stem of Trichosanthes cucumerina (L) var. cucumerina with reference to the influence of plant age and geographical variations". Journal of Pharmacy Research 10.10 (2016): 660-665.

41. Kuster V C and Vale F H. "Leaf histochemistry analysis of four medicinal species from Cerrado". Revista Brasileira de Farmacognosia 26.6 (2016): 673-678.

42. Sudipa M and Subrata M. "Studies on Screening And Histochemical Localisation Of Phytochemicals In The Medicinal Plant BarleriaLupulina Lindl”. IJPDT 4 (2014): 95-97.

43. Thushara $\mathrm{T}$ and Devipriya V. "Histochemical localization of starch, protein, lipid and lignin in the callus, field-grown and in vitro raised plants of Scopariadulcis L". International Journal of Scientific \& Engineering Research 8.9 (2017): 743-747.

44. Brammall R A and Hassan E A. "Histochemistry of wound healing response in roots of several hosts of Orobanche spp. The 61st Annual Meeting of the Canadian Phyopathological Society, Toronto, Ontario, Canada (1995): 43. 
45. Luthra R., et al. "Histochemical localization of citral accumulating site in lemongrass (Cymbopogonflexuosus Ness Ex. Steud) wats cultivar OD-19". Asian Journal of Plant Science 6 (2007): 419-422.

46. Gersbach P V., et al. "A New Histochemical Method for Localization of the Site of Monoterpene Phenol Accumulation in Plant Secretory Structures". Annals of Botany 88.4 (2001): 521-525.

47. Bedetti C S. "Detection of cytokinins and auxin in plant tissues using histochemistry and immunocytochemistry". Biotechnic \& Histochemistry 93.2 (2018): 1-6.

48. Spruce J., et al. "A Simple Histochemical Method for Locating Enzymes In Plant Tissue Using Nitrocellulose Blotting". Phytochemistry 26.11 (1987): 2901-2903.

49. Stomp A M. "Histochemical localization of $\beta$-glucuronidase. In: Gallagher SR (ed) GUSprotocols: using the GUS gene as a reporter of geneexpression". Academic Press San Diego (1992):103-113.

50. Azadi P., et al. "Macro elements ininoculation and co-cultivation medium stronglyaffect the efficiency of Agrobacteriummediatedtransformation in Lilium". Plant Cell Tissue Organization Culture 101.2 (2010): 201-209.

51. Sivaprakash K R., et al. "Tissue-specific histochemicallocalization of iron and ferritin gene expression intransgenic indica rice Pusa Basmati (OryzasativaL.)". Journal of Genetics 85.2 (2006): 157-160.

52. Chieco P., et al. "Image Cytometry:Protocols for 2D and 3D Quantification inMicroscopic Images". Progress in Histochemistry and Cytochemistry 47.4 (2013): 211-333.

53. Seregin I V and Kozhevnikova A D. "Histochemical methods for detection of heavymetals and strontium in the tissues of higher plants". Russian Journal of Plant Physiology 58.4 (2011): 721-727.

54. Warrier R R and Saroja S. "Histochemical studies on water hyacinth with particular references to water pollution". International Journal of Integrative Biology 3.2 (2008): 96-99.

55. Romero-Puertas M C., et al. "Cadmium-induced subcellular accumulation of $\mathrm{O}_{2}-$ and $\mathrm{H}_{2} \mathrm{O}_{2}$ in pea leaves". Plant Cell and Environment 27.9 (2004): 1122-1134.

56. Jin X., et al. "Effects of cadmium on ultrastructure andantioxidativedefense system in hyperaccumulator and non-hyperaccumulator ecotypes of Sedumal frediiHance". Journal of Hazardous Materials 156 (2008): 387-397.
57. Yamamoto Y., et al. "Lipid Peroxidation is an early symptom triggered by aluminum, but not the primary cause of elongation inhibition in pea roots". Plant Physiology 125.1 (2001): 199-208.

\section{Volume 3 Issue 7 July 2019}

(C) All rights are reserved by Farid A Badria and Walaa S Aboelmaaty. 